\title{
Plankton community composition in relation to availability and uptake of oxidized and reduced nitrogen
}

\author{
Gry Mine Berg ${ }^{1, *}$, Maija Balode ${ }^{2}$, Ingrida Purina ${ }^{2}$, Santa Bekere $^{2}$, Christian Béchemin $^{3}$, \\ Serge Y. Maestrini ${ }^{3}$ \\ ${ }^{1}$ Department of Marine Biogeochemistry, Institut für Meereskunde an der Universität Kiel, Düsternbrookerweg 20, \\ 24105 Kiel, Germany \\ ${ }^{2}$ Institute of Aquatic Ecology, University of Latvia, 3 Miera Street, Salaspils 2169, Latvia \\ ${ }^{3}$ Centre de Recherche en Ecologie Marine et Aquaculture de L'Houmeau (CNRS-IFREMER), BP 5, 17137 L'Houmeau, France
}

\begin{abstract}
Trends in nitrogen utilization, determined with ${ }^{15} \mathrm{~N}$-labeled substrates, were related to blooms of distinct phytoplankton groups in the Gulf of Riga, Baltic Sea, during May, June and July 1999. The dominant phytoplankton groups included diatoms, cryptophytes, dinoflagellates, and filamentous cyanobacteria. As the water column became progressively more stratified over the growing season, diatoms comprised a smaller proportion of the total phytoplankton assemblage and almost disappeared by late summer. Their disappearance correlated with undetectable surface-water nitrate concentrations and low nitrate uptake rates (5 to $8 \%$ of total nitrogen uptake). Diatoms were the only phytoplankton group significantly associated with the uptake of oxidized nitrogen (nitrate). Cryptophytes, filamentous cyanobacteria and dinoflagellates were significantly associated with uptake of reduced nitrogen including ammonium, urea, dissolved free amino acids and adenine. Our results indicate that uptake of oxidized and reduced forms of nitrogen can be separated in time and space due to association with distinct phytoplankton groups.
\end{abstract}

KEY WORDS: Nitrogen uptake $\cdot$ DON $\cdot$ Nitrate $\cdot$ Diatoms $\cdot$ Cyanobacteria $\cdot$ Cryptophytes $\cdot$ Baltic Sea Gulf of Riga

Resale or republication not permitted without written consent of the publisher

\section{INTRODUCTION}

One of the central issues in phytoplankton ecology is the identification of factors that allow certain phytoplankton species to gain an exclusive edge and dominate other species in the assemblage. General increases in phytoplankton biomass, as well as increases in frequency and duration of blooms of individual phytoplankton species, have been correlated with an overall increase in nutrient input to coastal regions (Smayda 1989, Hallegraeff 1993). Counterintuitive to this trend are reports that massive blooms of certain phytoplankton coincide with a decrease in nitrogen,

*Email: gberg@ifm.uni-kiel.de particularly nitrate. In Long Island coastal bays (New York, USA), blooms of the eukaryotic picoplankton Aureococcus anophagefferens occur mainly after nitrate and ammonium have decreased to the limit of detection (Keller \& Rice 1989, Smayda \& Villareal 1989). The observation that phytoplankton biomass increases despite low nitrate concentration can be explained by examining the availability of various forms of nitrogen and their relative rates of utilization among different phytoplankton. Typically, fast-growing diatoms are correlated with high fluxes of nitrate (Collos et al. 1992, 1997, Landry et al. 1997). In contrast, other phytoplankton taxa including cyanobacteria, eukaryotic picoplankton and autotrophic flagellates are correlated with high rates of reduced nitrogen supply, including dissolved organic nitrogen (DON) 
(Paerl 1991, Berg et al. 1997, Berman 1997, Carlsson et al. 1998).

With an increase in nutrient inputs to a system, there is a tendency for any extra nitrogen to be in the reduced form, and for the ratio of oxidized:reduced nitrogen to decrease (Oviatt et al. 1986). Studies suggest that decreasing the oxidized:reduced supply ratio may contribute disproportionately to the alteration of phytoplankton succession (LaRoche et al. 1997, Glibert \& Terlizzi 1999). For example, the Gulf of Riga, a subestuary of the Baltic Sea, has evidenced significant decreases in surface and deep water nitrate concentrations in the last 2 decades but an increase in phytoplankton biomass over the same period (Yurkovskis et al. 1996, 1999). Experiments carried out on natural populations and locally isolated algal strains from the Gulf of Riga suggested that cyanobacteria were able to sustain growth by uptake of DON substrates, potentially contributing to cyanobacterial dominance of summer assemblages (Balode et al. 1998, Maestrini et al. 1999). As measured by ${ }^{15} \mathrm{~N}$-labelled substrates, DON appeared to be a major source of nitrogen to phytoplankton in the river-influenced portion of the Gulf in summer (Berg et al. 2001). We expanded on these studies to identify specific trends in nitrogen utilization related to blooms of distinct phytoplankton groups which could serve as predictors of their occurrence.

The majority of nitrogen input to the Gulf of Riga occurs via riverine transport to the southern part, creating a north-south gradient in concentrations of nitrogen and salinity (Tamminen \& Seppälä 1999). In addition to riverine input, water column stratification influences nutrient distributions (Stipa et al. 1999). Variations in salinity, nutrients and degree of stratification along the north-south axis of the Gulf promote dominance of different phytoplankton populations (Seppälä \& Balode 1999). In the present study we examined surface water nitrogen concentrations, nitrogen uptake rates and plankton composition along the north-south axis of the Gulf during May, June and July 1999 to investigate relationships between specific taxonomic groups and flux of oxidized versus reduced forms of nitrogen.

\section{MATERIALS AND METHODS}

Study location. The Gulf of Riga is a sub-basin of the Baltic Sea connected to the Baltic proper by 2 straits (Fig. 1). The average depth of the Gulf is $26 \mathrm{~m}$, with a maximum depth of $62 \mathrm{~m}$ in the central part. Salinity ranges between 1 and 7 psu (this study: 1.6 and $6.7 \mathrm{psu}$ ) and is influenced by freshwater flow from several rivers in the southern and eastern parts of the Gulf, of which the Daugava River is the largest (Andrushaitis et al. 1995, Laznik et al. 1999). Five stations were sampled on May 6 to 10 , June 7 to 10 and July 27 to 30, 1999 (Fig. 1). The stations were located $4.2 \mathrm{~km}$ (Stn 101), $15.5 \mathrm{~km}$ (Stn 119), $46.1 \mathrm{~km}$ (Stn 121), $104.4 \mathrm{~km}$ (Stn 114) and $137.5 \mathrm{~km}$ (Stn 34) from the Daugava river mouth (Fig. 1). At each station, a vertical profile of salinity, temperature, and fluorescence (CTD) was recorded at 09:00 h. Nitrogen concentrations, uptake rates, and phytoplankton community structure were determined on $200 \mu \mathrm{m}$ filtered (Nitex mesh) surface water (0 to $2 \mathrm{~m}$ ) samples collected with Niskin $10 \mathrm{l}$ bottles. Rate measurements were carried out at 12:00 $\pm 2 \mathrm{~h}$. All incubations and filtrations were done on board the RV 'Arno'.

Analysis of dissolved nitrogen. Water samples for dissolved nitrogen determinations were filtered through combusted $\left(450^{\circ} \mathrm{C}, 1 \mathrm{~h}\right)$ Whatman GF/F filters. Concentrations of $\mathrm{NO}_{2}{ }^{-}+\mathrm{NO}_{3}{ }^{-}$and $\mathrm{NH}_{4}{ }^{+}$were measured with a Skalar autoanalyzer using standard analytical protocols (Valderrama

Fig. 1. Gulf of Riga. Inset: Baltic proper. o: Location of sampling stations 
1995). Urea was analyzed manually according to Koroleff (1983). Total dissolved nitrogen (TDN) was obtained by persulfate digestion followed by determination of $\mathrm{NO}_{3}^{-}$as described above. DON was calculated by subtracting concentrations of $\mathrm{NO}_{2}{ }^{-}+\mathrm{NO}_{3}{ }^{-}$and $\mathrm{NH}_{4}{ }^{+}$from TDN. Concentrations of dissolved free amino acids (DFAA) were measured as fluorescent OPA-derivatives by high-performance liquid chromatography (HPLC) according to Mopper \& Lindroth (1982).

Nitrogen rate measurements. Direct rates of nitrogen uptake were measured using ${ }^{15} \mathrm{~N}$ labeled $\mathrm{NH}_{4}{ }^{+}$, $\mathrm{NO}_{3}{ }^{-}$, urea, adenine and a mix of 3 amino acids (valine, leucine and aspartic). Because it is difficult to measure trace rates of nitrogen uptake accurately at low ambient concentrations, and because our goal was to examine relative rates of inorganic and organic nitrogen utilization, potential rates $\left(V_{\max }\right)$ were determined in the present study. The ${ }^{15} \mathrm{~N}$ substrates (>98\% enriched) were added to achieve a 95 to $99 \%$ enrichment of the dissolved nitrogen source pool. In June and July, additions of $10 \mu \mathrm{g}$ at $\mathrm{N}^{-1}$ were enough to achieve this level of saturation. In May, concentrations of $\mathrm{NO}_{3}{ }^{-}$were elevated at Stns 101 and 119 and additions of up to $80 \mu \mathrm{g}$ at ${ }^{15} \mathrm{NO}_{3}{ }^{-} \mathrm{l}^{-1}$ were needed to reach ${ }^{15} \mathrm{~N}$ saturation of the dissolved $\mathrm{NO}_{3}{ }^{-}$source pool. At Stn 119, the addition of $80 \mu \mathrm{g}$ at ${ }^{15} \mathrm{NO}_{3}^{-} \mathrm{l}^{-1}$ resulted in $85 \%$ saturation of the dissolved pool, slightly lower than the other samples. Duplicate, $500 \mathrm{ml}$ acid-rinsed polycarbonate incubation bottles were used to measure uptake of each substrate. Bottles were incubated in ambient seawater (4 to $9^{\circ} \mathrm{C}$ in May, 11 to $14^{\circ} \mathrm{C}$ in June, 17 to $20^{\circ} \mathrm{C}$ in July) under layers of neutral density screens to simulate the light level of sampling $(45 \%$ incident natural irradiance). Incubations were terminated after $1 \mathrm{~h}$ by filtration through pre-combusted GF/F filters $\left(500^{\circ} \mathrm{C}, 1 \mathrm{~h}\right)$ at low pressure $(<100 \mathrm{~mm} \mathrm{Hg})$. Filters were dried overnight at $50^{\circ} \mathrm{C}$ and packed in tin foil for ${ }^{15} \mathrm{~N}$ analysis. Samples were analyzed on a Europa 20/20 Isotope Ratio Mass Spectrometer (IRMS) with an attached ANCA S/L automated elemental analyzer (Europa Scientific). ${ }^{15} \mathrm{~N}$ atom percent and nitrogen mass were analyzed for each filter and nitrogen-specific uptake rates $\left(V_{\max }\right)$ were calculated using the equations of Dugdale \& Goering (1967)

$V_{\max }=\left({ }^{15} \mathrm{~N}_{\text {part }}-n a\right) /\left({ }^{15} \mathrm{~N}_{\text {diss }}-{ }^{15} \mathrm{~N}_{\text {part }}\right) \Delta T=$ time $^{-1}$

where na is the natural abundance $(0.366 \%),{ }^{15} \mathrm{~N}_{\text {diss }}$ is the isotopic ratio of the enriched dissolved pool, ${ }^{15} \mathrm{~N}_{\text {part }}$ is the atom percent abundance of the particulate matter, and $\Delta T$ is the time interval between samples.

Plankton community composition. Samples for phytoplankton community composition were preserved in Lugol's acid solution and settled using the Utermöhl method (Utermöhl 1958) before being counted on an in- verted microscope. The biomass $\left(\mu \mathrm{g} \mathrm{C}^{-1}\right)$ of each phytoplankton taxon was calculated from cell biovolumes. The biovolumes were calculated from cell dimensions measured with an eyepiece micrometer using formulas for geometric shapes (Edler 1979). Filamentous and colonial cyanobacteria were categorized separately from single-celled cyanobacteria labeled 'picocyanobacteria'. Samples for enumeration of picocyanobacteria and heterotrophic bacteria were preserved with $0.2 \mu \mathrm{m}$ filtered gluteraldehyde, final concentration 1 to $2 \%$. Preserved samples were filtered ( 5 to $10 \mathrm{ml}$ ) onto $0.2 \mu \mathrm{m}$ blackened polycarbonate filters (Millipore) and stained with DAPI (4'-6-diamidino-2phenylindole). Cells were counted with a Leitz Dialux epifluorescence microscope fitted with a $100 \times 1.25 \mathrm{ob}-$ jective. Picocyanobacteria were distinguished from heterotrophic bacteria by switching between a green filter and UV excitation. Abundances of picocyanobacteria and heterotrophic bacteria, reported as the means of 20 fields per sample, were converted to carbon biomass according to Lee \& Fuhrman (1987). At least 500 heterotrophic bacteria were counted per filter.

\section{RESULTS}

Vertical profiles of temperature, salinity, density and chlorohpyll a (chl a) concentration differed between season and location along the estuarine gradient. In spring, the vertical density gradient became shallower, progressing from offshore (Stn 34; Baltic Sea station) to nearshore (Stn 101; Fig. 2A-C). There was no pycnocline at Stn 34 (Fig. 2A), a weak pycnocline at $14 \mathrm{~m}$ at Stn 121 (Fig. 2B), and a stronger pycnocline at $10 \mathrm{~m}$ at Stn 101 (Fig. 2C). At Stn 101, there was also a weak pycnocline at 2 to $3 \mathrm{~m}$ (Fig. 2C). Chl a concentration decreased 67 to $77 \%$ between the upper mixed layer and the bottom layer at all stations (Fig. 2A-C).

In summer, all stations were stratified. As in spring, the pycnocline became progressively shallower toward the Daugava river mouth (Fig. 2D-F). The pycnocline varied from 22 to $30 \mathrm{~m}$ at Stn 34 (Fig. 2D), 16 to $20 \mathrm{~m}$ at Stn 121 (Fig. 2E), to $14 \mathrm{~m}$ at Stn 101 (Fig. 2F). Chl a concentration decreased by 50 to $55 \%$ from the upper mixed layer to the lower layer of the water column at all stations (Fig. 2D-F).

Concentrations of nitrogen decreased from the Daugava river mouth (nearshore) to the open Baltic (offshore) during all 3 sampling times (with the exception of $\mathrm{NO}_{3}{ }^{-}$in July), but the decrease was greatest in May and June compared to July (Fig. 3A-C). In May, $\mathrm{NO}_{2}{ }^{-}+\mathrm{NO}_{3}{ }^{-}$decreased $\sim 100 \%$, DFAA decreased $60 \%$, and DON decreased $50 \%$ from the nearshore to offshore stations. The ratio of oxidized:reduced nitrogen decreased from 0.35 to 0.44 nearshore to 0.0005 

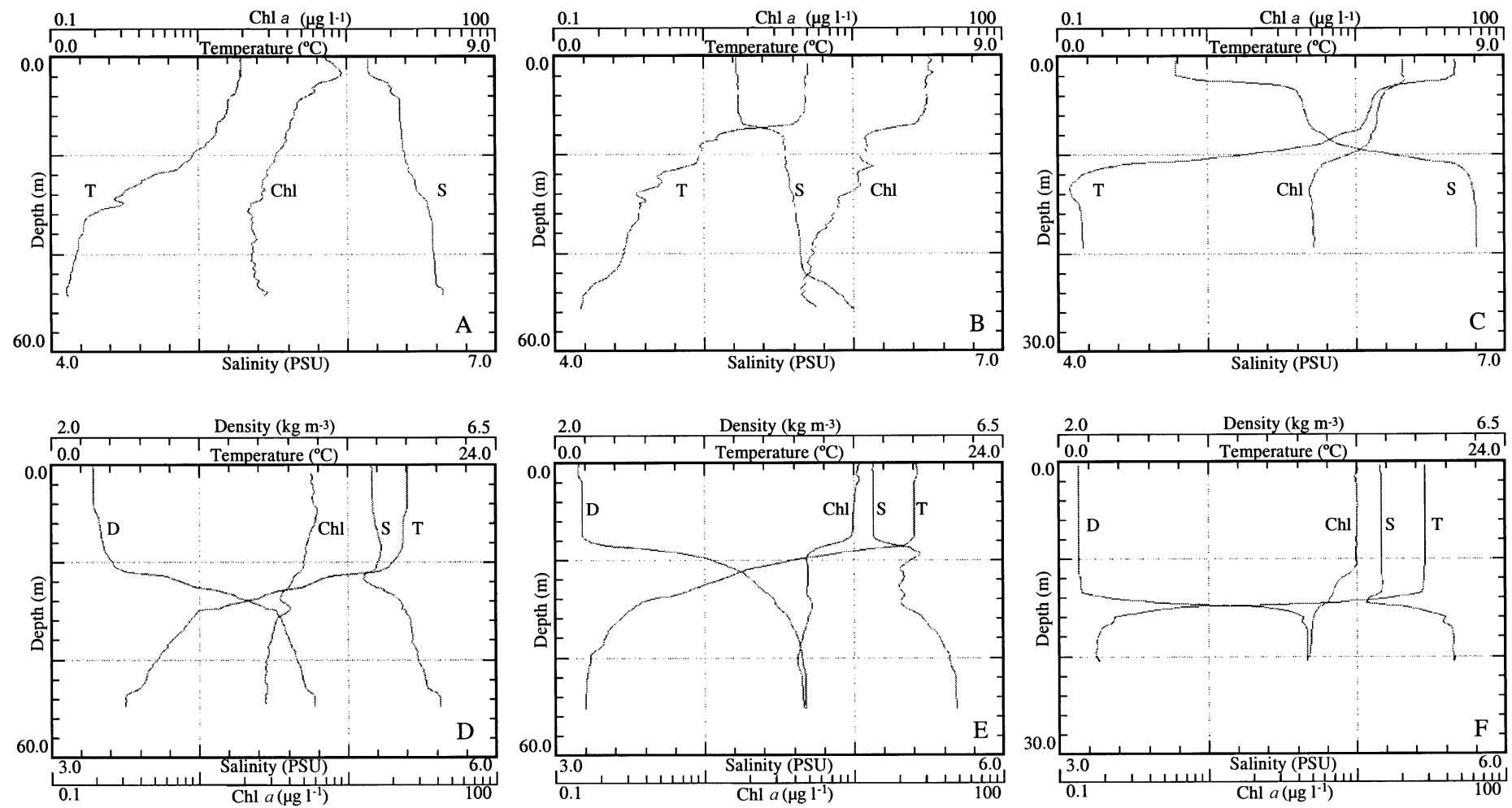

Fig. 2. Chl a, temperature, and salinity as a function of depth in May at (A) Stn 34, (B) Stn 121, and (C) Stn 101. Chl a, temperature, salinity and density as a function of depth in July at (D) Stn 34, (E) Stn 121, and (F) Stn 101. Note differing vertical scales among panels

offshore (Fig. 3A). In June, $\mathrm{NO}_{2}{ }^{-}+\mathrm{NO}_{3}{ }^{-}$decreased $97 \%$, DFAA decreased $76 \%$, and DON decreased $37 \%$, and the oxidized:reduced nitrogen ratio decreased from 0.1 to 0.002 to 0.005 (Fig. 3B). In July, $\mathrm{NO}_{2}^{-}+\mathrm{NO}_{3}{ }^{-}$increased $66 \%$, and DFAA and DON decreased only 27 and $24 \%$, respectively, from the nearshore to offshore stations. The oxidized:reduced nitrogen ratio was similar at all stations (Fig. 3C). While $\mathrm{NO}_{2}^{-}+\mathrm{NO}_{3}{ }^{-}$concentration increased from nearshore to offshore stations in July, concentrations were 1 to 2 orders of magnitude less compared with May and June. Concentrations of $\mathrm{NH}_{4}{ }^{+}$and urea did not vary horizontally in the Gulf. In May and June, concentrations of urea and $\mathrm{NH}_{4}{ }^{+}$were 3 and $2 \mu \mathrm{M}$, respectively, and in July they were 2 and $1 \mu \mathrm{M}$. During all sampling periods, DON comprised the largest pool of available nitrogen in the Gulf. In May DON comprised between 68 and $95 \%$, in June 81 and $95 \%$, and in July 96 and $99 \%$ of TDN.

Phytoplankton biomass $\left(\mu \mathrm{C}^{-1}\right)$ in May varied between 250 and $700 \mu \mathrm{g} \mathrm{C}^{-1}$ in the Gulf and $50 \mu \mathrm{g} \mathrm{C}$ $\mathrm{I}^{-1}$ in the Baltic Sea (Fig. 4A). At this time, diatoms and dinoflagellates comprised 25 to 60 and $40 \%$, respectively, of phytoplankton standing stock. Closer to the Daugava River, cryptophytes comprised 20 to $40 \%$ of community composition, while at the open Baltic station, filamentous cyanobacteria dominated total phytoplankton biomass composition (Fig. 4B).
In June, there was a window of low phytoplankton biomass (6 to $60 \mathrm{\mu g} \mathrm{C}^{-1}$ ) following the decline of the diatom bloom (Fig. 4C). At the nearshore station (Stn 101), diatoms comprised $83 \%$ of total phytoplankton biomass, while cyanobacteria dominated the Baltic station (Stn 34), comprising $85 \%$ of total phytoplankton biomass (Fig. 4D). In the middle of the Gulf, phytoplankton biomass was 3- to 10-fold lower than at the nearshore or Baltic stations (Fig. 4C), and dinoflagellates, chlorophytes, and filamentous cyanobacteria contributed equally to phytoplankton community composition (Fig. 4D). At the Strait of Irbe (Stn 114), cryptophytes comprised approximately $50 \%$ of total phytoplankton biomass (Fig. 4D).

In July, phytoplankton biomass increased from the Daugava River $\left(52 \mu \mathrm{g} \mathrm{C} \mathrm{l}^{-1}\right)$, towards the Baltic $\left(545 \mu \mathrm{g} \mathrm{Cl}^{-1}\right)$ (Fig. 4E). At the nearshore stations, cryptophytes comprised 60 to $80 \%$ of total phytoplankton biomass; in the middle of the Gulf cryptophytes and filamentous cyanobacteria comprised approximately $40 \%$ each, and at the Strait of Irbe and the open Baltic stations filamentous cyanobacteria contributed 76 to $95 \%$ to total phytoplankton biomass (Fig. 4F).

Biomass of picocyanobacteria varied between 3 and $10 \mathrm{\mu g} \mathrm{Cl}^{-1}$ in May and July in the Gulf (Fig. 5A). In June, biomass of picocyanobacteria peaked at $>25 \mu \mathrm{g} \mathrm{Cl}^{-1}$ at the nearshore station (Stn 101), decreasing $66 \%$ by 
Stn 121 (Fig. 5A). At the Baltic station (Stn 34) biomass measured $3 \mu \mathrm{g} \mathrm{Cl}^{-1}$ (Fig. 5A). Bacterial biomass was greater than that of picocyanobacteria during all 3 sampling months. In May, biomass of bacteria varied little throughout the estuary (Fig. 5B). In June there was a $77 \%$ decrease from Stn 101 to Stn 121, similar to the decrease in biomass of picocyanobacteria (Fig. 5A,B), while in July, there was an $80 \%$ increase between Stn 121 and Stn 34 (Fig. 5B).

In May, potential rates of $\mathrm{NO}_{3}{ }^{-}, \mathrm{NH}_{4}{ }^{+}$and DFAA uptake $\left(\mathrm{h}^{-1}\right)$ decreased 68,52 , and $74 \%$, respectively, going from the Daugava river mouth towards the Baltic (Fig. 6A). At this time, rates of urea and adenine uptake remained relatively unchanged across the Gulf (Fig. 6A). Potential rates of adenine uptake were an order of magnitude less than the other $\mathrm{N}$-substrates tested and did not contribute more than $7 \%$ of total nitrogen uptake (Fig. 6A,B). Overall, $\mathrm{NO}_{3}{ }^{-}$contributed most to total $\mathrm{N}$ uptake ( 25 to $47 \%$ ), followed by $\mathrm{NH}_{4}{ }^{+}$(32 to $43 \%$ ) (Fig. 6B). Potential uptake of DFAA represented $22 \%$ of total $\mathrm{N}$ uptake at the nearshore station, decreasing to $4 \%$ in the middle and increasing to $13 \%$ at the Baltic station (Fig. 6B). The contribution of $\mathrm{NO}_{3}{ }^{-}$to total $\mathrm{N}$ uptake was significantly less at the Baltic Sea station (Stn 34) than at the Gulf of Riga stations (Fig. 6B).

In June, the highest rates of nitrogen uptake occurred at Stn 114, in the Strait of Irbe. Here, rates of reduced nitrogen uptake were 3- to 7 -fold faster than the rate of $\mathrm{NO}_{3}^{-}$(Fig. 6C). Potential rates of $\mathrm{NH}_{4}{ }^{+}$and urea uptake were 1.6 and 11 times greater, respectively, at Stn 114 compared to Stn 21 (Fig. 6C). Potential adenine uptake was relatively high nearshore (Stns 101 and 119), as well as at Stn 114, where it contributed between 8 and $10 \%$ of total nitrogen uptake (Fig. 6C,D). Potential rates of amino acid uptake contributed between 7 to $13 \%$ to total nitrogen uptake. Similarly, the contribution of $\mathrm{NO}_{3}{ }^{-}$was $13 \%$ or less at all stations (Fig. 6D). The contribution of urea to total nitrogen uptake increased from 8 to $30 \%$ between Stns 121 and 114, decreasing slightly again at Stn 34 (Fig. 6D). Uptake of $\mathrm{NH}_{4}^{+}$contributed most (52 to $63 \%$ ), to total nitrogen uptake in June.

In July, potential rates of $\mathrm{NH}_{4}{ }^{+}$uptake were higher in the Gulf compared to the open Baltic station, while potential rates of urea uptake were greater at Stns 119, 121, and 114, compared with Stns 101 (nearshore) and 34 (open Baltic) (Fig. 6E). Urea contributed more to total nitrogen uptake (22 to $37 \%$ ), than in May and June. Ammonium contributed 46 to $60 \%$ of total nitrogen uptake (Fig. 6F). Potential amino acid and adenine uptake contributed 6 to $11 \%$ (combined) and $\mathrm{NO}_{3}{ }^{-}$contributed 5 to $10 \%$ of total nitrogen uptake (Fig. 6F).

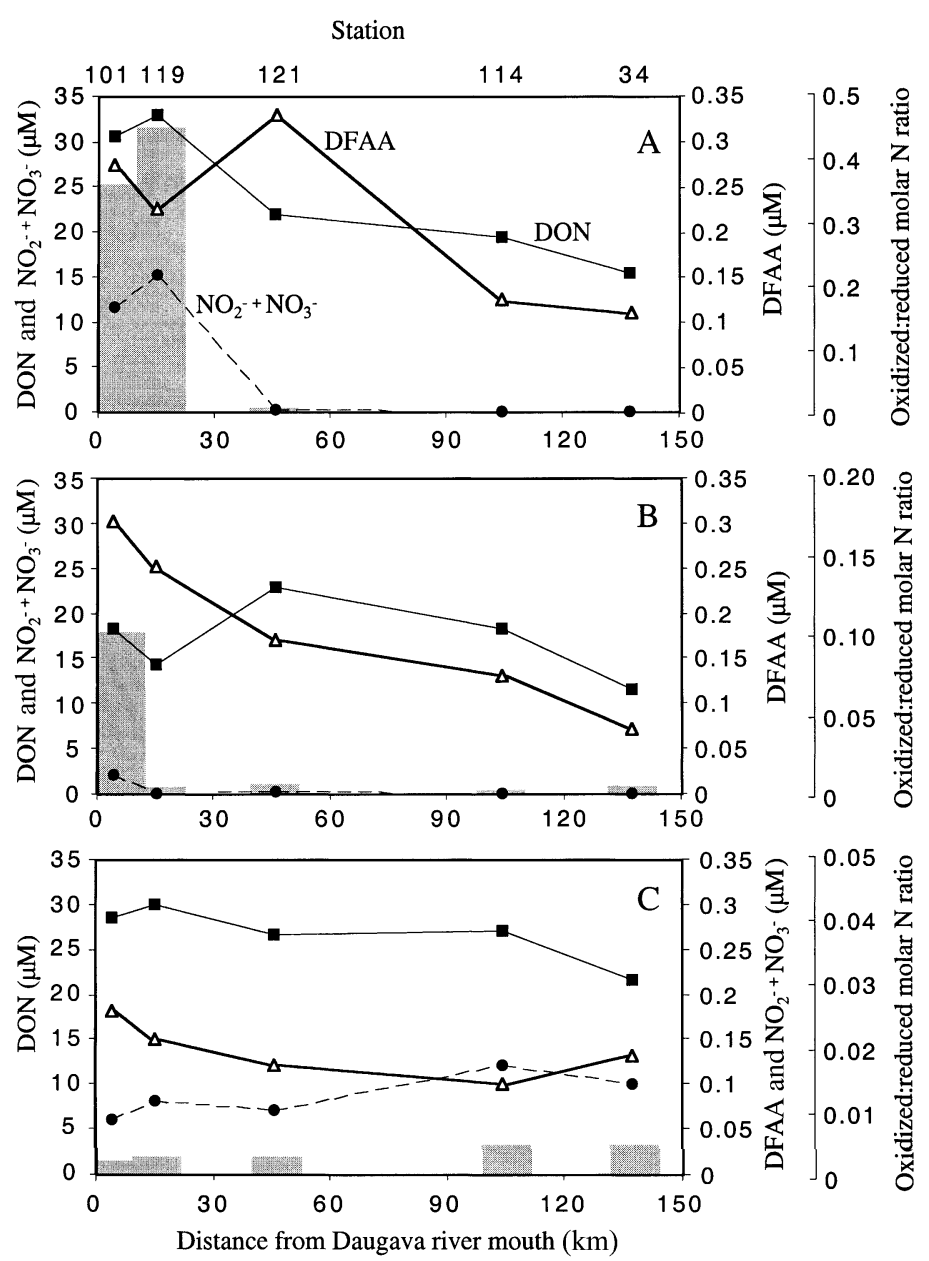

Fig. 3. Changes in concentrations of nitrate $(\bullet)$, DFAA $(\Delta)$, and dissolved organic nitrogen (DON) ( $\bullet$ ) in the Gulf of Riga in (A) May, (B) June, and (C) July. Grey bars denote the oxidized: reduced molar nitrogen ratio

\section{DISCUSSION}

Terrestrial run-off and riverine input of both inorganic and organic nutrients to coastal regions may be considerable (Meybeck 1982). The Daugava River has been shown to be a major source of nitrogen to the Gulf of Riga (Maestrini et al. 1999, Stålnacke et al. 1999, Tamminen \& Seppälä 1999), which in turn has a significant impact on the microbial community and nitrogen cycling of the southern region (Jørgensen et al. 1999, Berg et al. 2001). River runoff, typically varying from $2000 \mathrm{~m}^{3} \mathrm{~s}^{-1}$ in spring to less than $200 \mathrm{~m}^{3}$ $\mathrm{s}^{-1}$ in late summer, creates a horizontal gradient in salinity and nutrients from the river mouth in the south to the Baltic Sea in the north (Laznik et al. 1999, Stålnacke et al. 1999). In this study we found that as the salinity differential between the upper and lower layers of the water column decreases with 

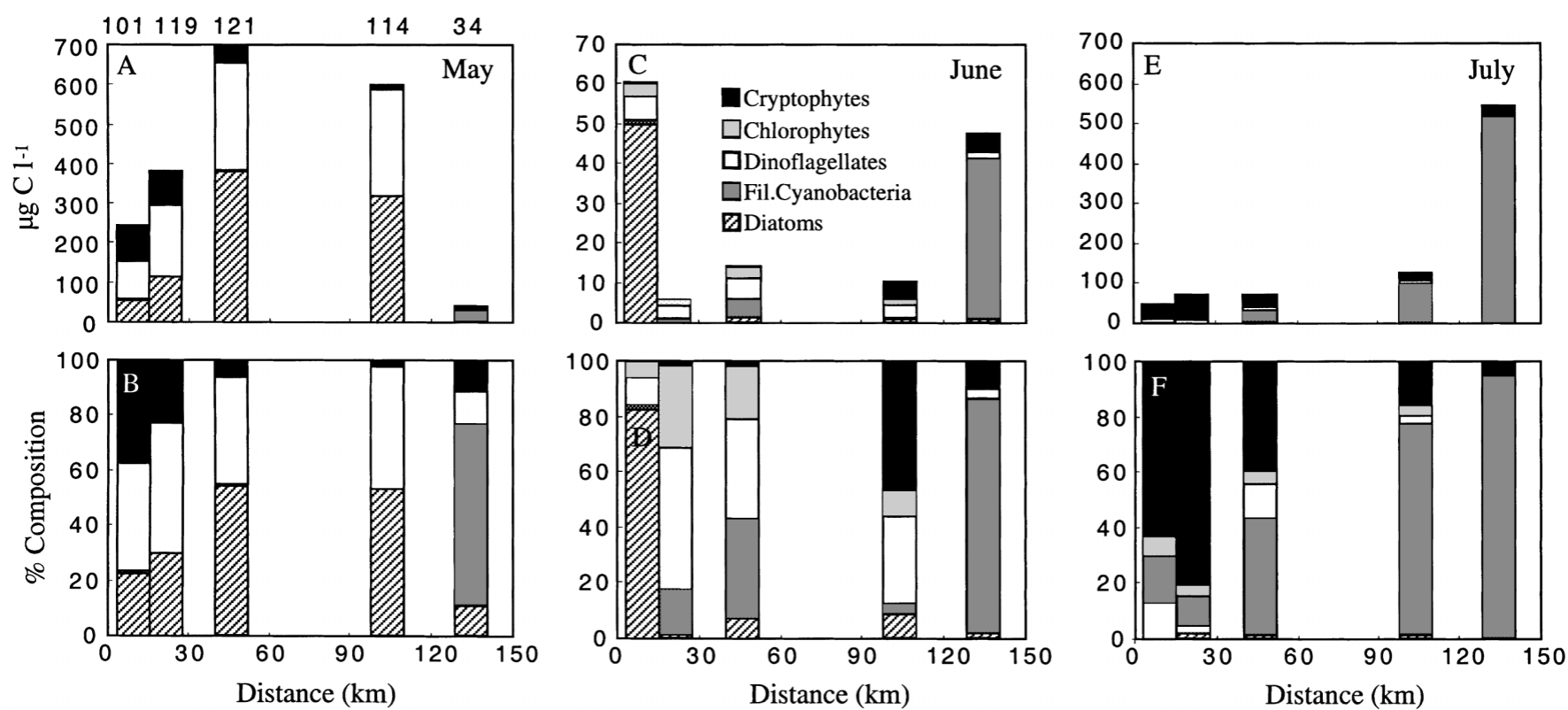

Fig. 4. Phytoplankton biomass $\left(\mu \mathrm{g} \mathrm{Cl}^{-1}\right)$, and biomass of each phytoplankton group as a percent of total phytoplankton (cryptophytes + chlorophytes + dinoflagellates + filamentous cyanobacteria + diatoms) in (A,B) May, (C,D) June, and (E,F) July

distance from the Daugava river mouth, the mixed layer-depth deepens, and nitrogen pools become increasingly diluted. The extent to which differences in pool sizes of oxidized and reduced nitrogen along

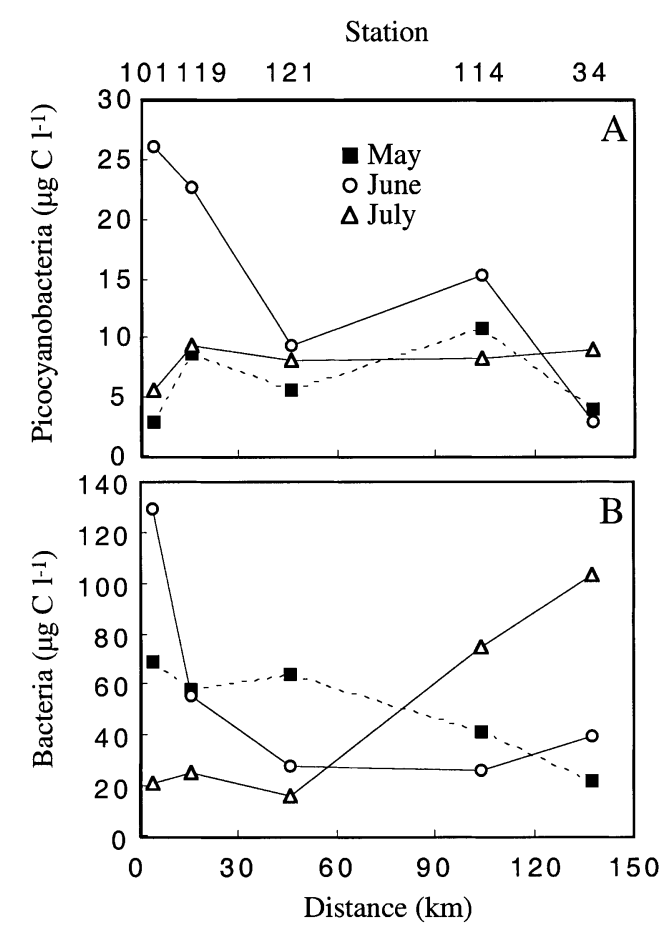

Fig. 5. Changes in biomass of (A) picocyanobacteria and (B) heterotrophic bacteria with distance of the Daugava river mouth in May, June, and July the south-north axis of the Gulf control community composition is of considerable interest from the perspective of understanding plankton succession in this area.

\section{Plankton succession}

The abundance and biomass of both cryptophytes and filamentous cyanobacteria has increased in the Gulf of Riga in the last decade (Kahru et al. 1994, Balode \& Purina 1996, Seppälä \& Balode 1999), apparently correlating with an overall decrease in river flow and nutrients (Laznik et al. 1999, Yurkovskis et al. 1999). The present study saw a significant increase in the biomass of filamentous cyanobacteria between spring and late summer samplings, as well as an 11- to 78-fold increase from the Daugava River to the open Baltic Sea. The increase in cyanobacterial biomass was consistent with increased mixing depth and increased dilution of riverine nitrogen.

Based on our observations, diatoms were mainly present in May when $\mathrm{NO}_{3}{ }^{-}$was an important source of nitrogen. Following a decrease in river flow and surface water $\mathrm{NO}_{3}{ }^{-}$in June, the diatoms retreated to the mouth of the river. In July, they disappeared almost entirely from the phytoplankton assemblage. This was unusual as diatoms typically contribute up to $50 \%$ of total phytoplankton biomass in July (Balode \& Purina 1996, Balode et al. 1998, Seppälä \& Balode 1999, Berg et al. 2001). Their disappearance coincided with undetectable surface-water $\mathrm{NO}_{3}{ }^{-}$concentrations and low 


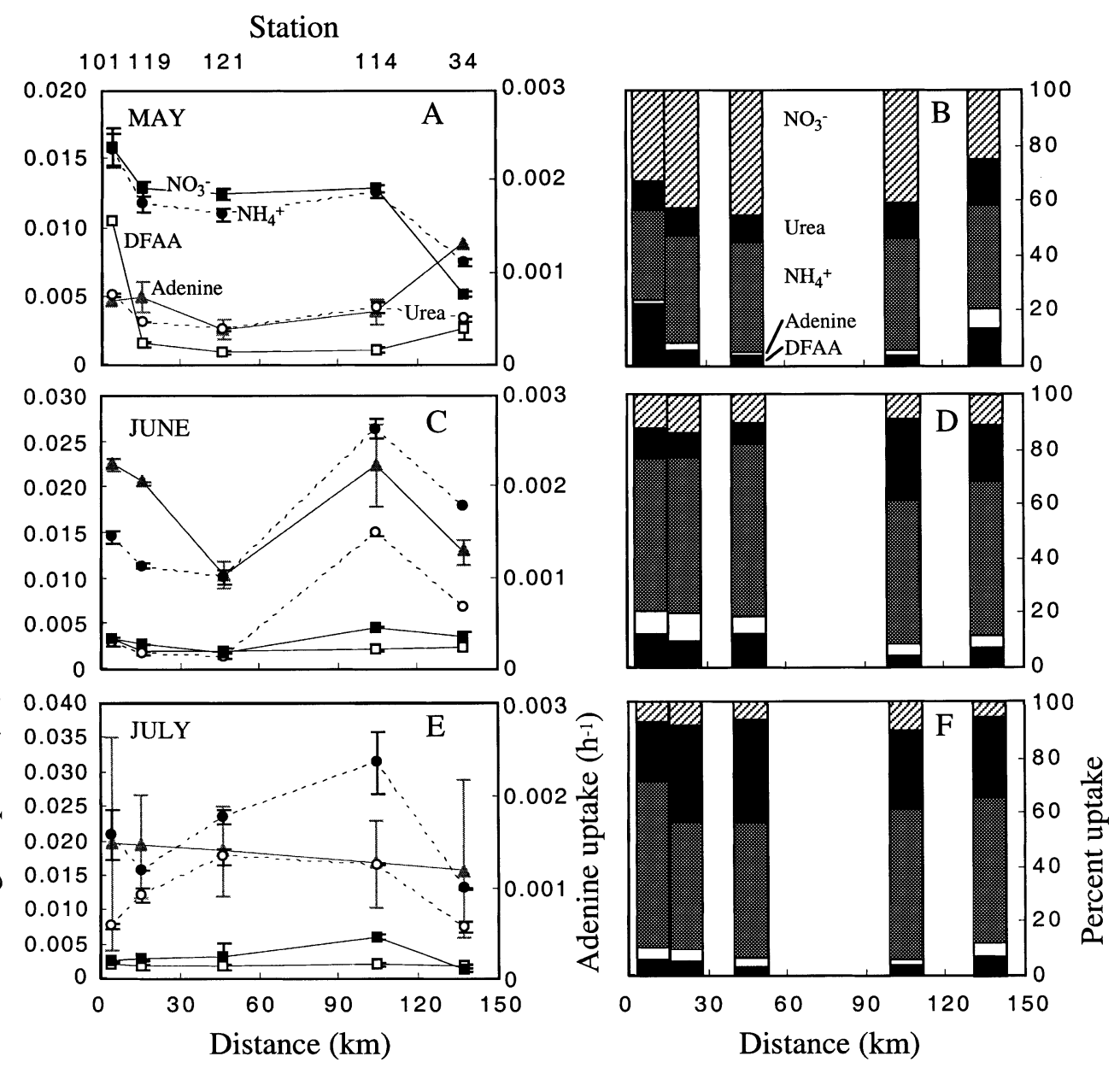

Fig. 6. Nitrogen-specific rates of uptake, $\mathrm{NO}_{3}^{-}(\mathbf{\bullet}), \mathrm{NH}_{4}{ }^{+}(\bullet)$, DFAA (ㅁ), urea (o), adenine (\$) and uptake of each nitrogen substrate as a percent of total nitrogen $\left(\mathrm{NO}_{3}{ }^{-}+\mathrm{NH}_{4}{ }^{+}+\right.$urea + adenine + DFAA) uptake in $(\mathrm{A}, \mathrm{B}) \mathrm{May},(\mathrm{C}, \mathrm{D}) \mathrm{June}$ and $(\mathrm{E}, \mathrm{F})$ July

nitrate uptake rates (5 to $8 \%$ of total nitrogen uptake), suggesting that in the absence of $\mathrm{NO}_{3}{ }^{-}$they may have been out-competed for other sources of nitrogen. While silicate is generally considered to limit diatom growth, it has not been shown to restore the growth capacity of summer diatom populations in recent bioassay experiments in the Gulf of Riga (Maestrini et al. 1997, Balode et al. 1998). The association between diatom biomass and periodic inputs of $\mathrm{NO}_{3}{ }^{-}$concurs with investigations of both coastal and oligotrophic environments (e.g. Malone et al. 1983, Goldman 1993, Landry et al. 1997, Lomas \& Glibert 1999).

\section{Taxon-specific nitrogen uptake}

Linear regression analysis was conducted to examine the relationship between phytoplankton groups and uptake of specific nitrogen substrates. Assuming that each phytoplankton group mainly utilized 1 source of nitrogen, we analyzed the percent biomass of individual phytoplankton groups as a function of percent nitrogen-specific uptake. This type of analysis potentially avoids difficulties associated with size fractionation to differentiate between phytoplankton groups, and between phytoplankton and heterotrophic bacteria (Wheeler \& Kirchman 1986, Hoch \& Kirchman 1995).

Our results indicated that only diatoms were associated with uptake of $\mathrm{NO}_{3}^{-}$(Table 1). In the absence of diatoms, other phytoplankton did not appear to utilize $\mathrm{NO}_{3}{ }^{-}$, even large cells such as dinoflagellates. Although the exact mechanisms leading to differences in the nitrogen metabolism between diatoms and other phytoplankton are currently not identified, diatoms potentially take up $\mathrm{NO}_{3}{ }^{-}$in excess of nutritional requirements to serve as a sink for electrons during periods of imbalance between light energy harvesting and utilization (Lomas \& Glibert 1999). This mechanism is apparently not present in non-diatom species 
Table 1. Linear regression of percent biomass $(B)$ of individual phytoplankton groups $-B_{\text {ind }}\left(\mathrm{C}^{-1}\right) /\left[B_{\text {cryptophytes }}+B_{\text {chlorophytes }}+\right.$ $\left.B_{\text {dinoflagellates }}+B_{\text {fil.cyanobacteria }}+B_{\text {diatoms }}\left(\mathrm{C}^{-1}\right)\right] \times 100$ - as a function of percent nitrogen uptake $(V)-V_{\mathrm{s}}\left(\mathrm{h}^{-1}\right) /\left[V_{\mathrm{NO}_{3}}+V_{\mathrm{NH}_{4}}+\right.$ $\left.V_{\text {urea }}+V_{\text {DFAA }}+V_{\text {adenine }}\left(\mathrm{h}^{-1}\right)\right] \times 100$

\begin{tabular}{|llccc|}
\hline Taxon & Substrate & $\mathrm{r}^{2}$ & $\mathrm{p}$ & Month \\
\hline Diatoms & Nitrate & 0.8 & 0.040 & May \\
Cryptophytes & Ammonium & 0.81 & 0.037 & May \\
& Amino acid mix & 0.80 & 0.040 & June \\
& Urea & 0.84 & 0.020 & June \\
Cyanobacteria $^{\mathrm{a}}$ & Adenine & 0.96 & 0.003 & May \\
Dinoflagellates $^{2}$ & Adenine & 0.82 & 0.033 & May \\
aFilamentous cyanobacteria only & & & \\
\hline
\end{tabular}

such as dinoflagellates (Lomas \& Glibert 1999). Conversely, dinoflagellates and other phytoplankton may have specialized cell-surface enzymes for hydrolysis of organic nitrogen substrates that are not present in diatoms (Palenik \& Morel 1990).

In contrast to the diatoms, cryptophytes, dinoflagellates and filamentous cyanobacteria were associated with uptake of reduced nitrogen substrates including $\mathrm{NH}_{4}{ }^{+}$, urea, DFAA and adenine (Table 1). In May, biomass of dinoflagellates and filamentous cyanobacteria varied as a function of organic nitrogen uptake (Table 1). While adenine has been shown to provide a source of nitrogen for growth in some eukaryotic phytoplankton (Antia et al. 1991), uptake of this nitrogen source did not exceed $7 \%$ of total nitrogen uptake and probably contributed a minor part of dinoflagellate and cyanobacterial nitrogen demand. At this time, changes in biomass of dinoflagellates and cyanobacteria were most closely associated with variability in urea uptake ( $\mathrm{r}^{2}=0.6$ to 0.7 , not significant). Later in June, variation in cryptophyte biomass explained 80 to $84 \%$ of the variability in uptake of urea and DFAA (Table 1). In July, there was a clear lack of association between algal taxa and uptake of specific nitrogen substrates. This may have been because the dominant groups, cryptophytes and filamentous cyanobacteria, were using more than 1 source of nitrogen simultaneously, including $\mathrm{NH}_{4}{ }^{+}$and urea, and atmospheric nitrogen in the case of the cyanobacteria.

Cryptophytes commonly bloom in the Gulf of Riga (Balode et al. 1998, Berg et al. 2001) and other coastal regions rich in organic nitrogen (Lewitus \& Kana 1994). Consistent with utilization of organic nitrogen, specific strains of cryptophytes are incapable of growth on $\mathrm{NO}_{3}^{-}$as the sole source of nitrogen in culture (Droop 1957), preferring organic nitrogen substrates such as urea, purines and aminosugars (Antia \& Chorney 1968). In the present investigation, cryptophytes dominated pockets of the Gulf where rates of reduced nitrogen uptake were high and percent uptake of urea, amino acids and $\mathrm{NH}_{4}{ }^{+}$varied with percent cryptophyte biomass (Table 1). For example, in June cryptophyte biomass was greatest at the Strait of Irbe, where the turnover of $\mathrm{NH}_{4}{ }^{+}$and urea ( 8 to $30 \mathrm{~h}$ ) was 2 to 11 times greater than at any other station in the Gulf. High rates of reduced nitrogen turnover suggested that a source of regenerated nitrogen, possibly from the sediments, created a favorable environment for cryptophyte growth in this region. Similarly, cryptophytes were dominant close to the Daugava river mouth in late summer, where the ratio of oxidized:reduced nitrogen had decreased from spring, when diatoms were favored. In this region, DON uptake rates may be 6 times greater than in other parts of the Gulf, suggesting that the resident populations actively incorporate organic nitrogen substrates (Berg et al. 2001).

Similar to the cryptophytes, filamentous cyanobacteria appeared to utilize $\mathrm{NH}_{4}{ }^{+}$and urea as sources of nitrogen in June and July (Figs. 4 \& 6). Filamentous cyanobacteria such as Nodularia sp., Aphanizomenon sp. and Anabaena sp. also fix $\mathrm{N}_{2}$ gas, which is clearly advantageous when fixed nitrogen is limiting in surface waters (Stal \& Walsby 1998, Stal et al. 1999). In the Baltic proper, aggregates of Aphanizomenon sp. typically represent 20 to $30 \%$ of total cyanobacterial biomass while picocyanobacteria represent $70 \%$ of the biomass (Stal et al. 1999, Stal \& Walsby 2000). Therefore, it is likely that the picocyanobacterial fraction is important in the turnover of fixed, reduced nitrogen. For example, Söresson \& Sahlsten (1987) concluded that $84 \%$ of total nitrogen utilization $\left(\mathrm{NH}_{4}{ }^{+}+\mathrm{NO}_{3}{ }^{-}+\right.$urea $\left.+\mathrm{N}_{2}\right)$ during a bloom of filamentous cyanobacteria was attributable to non-nitrogen-fixing picocyanobacteria. This case cannot always be made in the Gulf of Riga, where the abundance of filamentous cyanobacteria can be much greater than that of picocyanobacteria. In the present study, picocyanobacteria comprised 8 and $1.5 \%$ of total cyanobacterial biomass in June and July, respectively, at the outer stations, where some of the most rapid rates of $\mathrm{NH}_{4}{ }^{+}$and urea uptake and turnover occurred. Here, filamentous cyanobacteria contributed between 80 and $95 \%$ of total phytoplankton biomass, suggesting unrealistic rates of $\mathrm{NH}_{4}{ }^{+}$and urea uptake by the rest of the community if the nitrogen demand of the filamentous cyanobacteria were met solely by $\mathrm{N}_{2}$ fixation. At the outermost station, the absolute rate of nitrogen uptake by cyanobacteria was 9 to 20 times greater than by cryptophytes, the second largest constituent of the phytoplankton community (Fig. 7). The highest rate of absolute nitrogen uptake by cryptophytes was observed at Stn 119 in July (Fig. 7), where filamentous cyanobacteria contributed a negligible proportion of the phytoplankton community (Fig. 4). Taking this rate as a benchmark, fixed nitrogen uptake by filamentous cyanobacteria was still 6 times greater 
than the maximum observed cryptophyte uptake rate (Fig. 7). This suggests that either filamentous cyanobacteria play an important role in uptake and assimilation of fixed nitrogen, or associated heterotrophic bacteria play a greater role than previously recognized.

Heterotrophic bacteria mediate nitrogen remineralization in the Gulf of Riga and potentially impact rates of inorganic nitrogen uptake (Jørgensen et al. 1999). Biological production and riverine input of DON in summer contribute abundant dissolved free and combined amino acids to bacteria for assimilation (Jørgensen et al. 1999). Under these conditions, gross bacterial DFAA uptake exceeds nitrogen demand several-fold and bacteria act mainly as remineralizers of inorganic nitrogen rather than as net consumers (Berg et al. 2001). Therefore, in eutrophic coastal regions bacteria tend to compete for $\mathrm{NH}_{4}{ }^{+}$only when DFAA abundance is low (Keil \& Kirchman 1991, Hoch \& Kirchman 1995). In the present study, it is possible that DON excreted by the filamentous cyanobacteria supported biomass of heterotrophic bacteria, and that the 2 groups did not compete for inorganic nitrogen uptake (Ohlendieck et al. 2000).

Nitrogen fixation is a significant source of new nitrogen in oligotrophic regions (Carpenter 1983, Karl et al. 1997). Even in eutrophic regions such as the Baltic Sea, nitrogen fixation is considered the third largest source of new nitrogen after land runoff and atmospheric deposition (Larsson et al. 2001). Field studies from the Baltic indicate that nitrogen fixation is the dominant process by which filamentous heterocystous cyanobacteria acquire nitrogen (Stal \& Walsby 1998, 2000). These findings are not corroborated by culture and molecular biological investigations demonstrating that $\mathrm{N}_{2}$ fixation in filamentous cyanobacteria is strictly regulated by the availability of $\mathrm{NH}_{4}{ }^{+}$(Sanzalferez \& Delcampo 1994). In all nitrogen-fixing, non-fixing, unicellular and filamentous cyanobacteria, synthesis of the global regulatory protein NtcA is necessary for the induction of proteins required for the utilization of nitrogen substrates other than $\mathrm{NH}_{4}{ }^{+}$(Frias et al. 1993, 1994, Bryant 1994, Bradley \& Reddy 1997, Collier et al. 1999, Lindell \& Post 2001). Because $\mathrm{N}_{2}$ fixation is an energy-expensive process, requiring 15 molecules of ATP and 6 to 8 electrons per molecule of $\mathrm{N}_{2}$ reduced to $\mathrm{NH}_{4}{ }^{+}$(Postgate 1982), differentiation of heterocysts in filamentous cyanobacteria is strictly regulated by the feedback of fixed nitrogen on NtcA transcription (Stewart \& Rowell 1975, Frias et al. 1994, Fiedler et al. 2001). Whether NtcA transcriptional activation in filamentous cyanobacteria is also subject to negative control by urea is not known.

The role of urea in the nitrogen nutrition of field populations of filamentous cyanobacteria has puzzled investigators who have observed relatively high rates

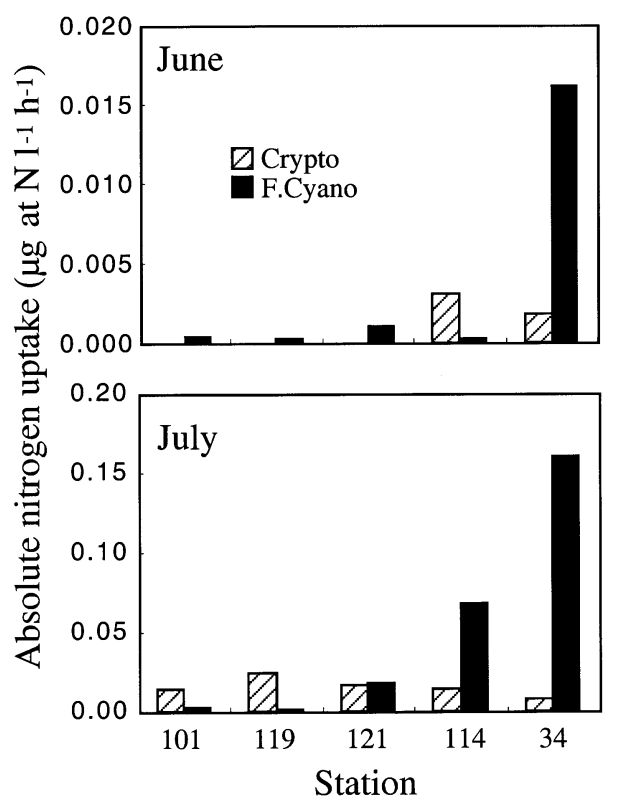

Fig. 7. Absolute nitrogen uptake rates, $\rho_{\max }$ (transport rates), were based on Dugdale \& Goering (1967), where $\rho_{\max }(\mu \mathrm{g}$ at $\mathrm{N}$ $\left.\mathrm{l}^{-1} \mathrm{~h}^{-1}\right)=V_{\max }\left(\mathrm{h}^{-1}\right) \times \mathrm{PN}(\mu \mathrm{M})$. Absolute nitrogen uptake rates for individual phytoplankton groups were calculated by multiplying the nitrogen-specific rate, $V_{\max }$, by the group-specific PN. Group-specific PN was obtained by dividing carbon biomass $(\mu \mathrm{MC})$ of individual groups by 6.625 according to the Redfield ratio. Calculation of absolute nitrogen uptake rates by this method assumes that the fraction of a certain group present is responsible for that same fraction of the community-specific uptake rate that was actually measured

of urea uptake during blooms in the Baltic Sea (Söresson \& Sahlsten 1987). Only recently have culture experiments corroborated field observations. In culture investigations of Aphanizomenon ovalisporum, growth and yield were consistently greatest when urea was the sole source of nitrogen for growth, agreeing with observations in culture studies of the non-heterocystous diazotroph Trichodesmium sp. (Berman \& Chava 1999). Trichodesmium sp. demonstrated highest growth and nitrogen turnover rates in cultures grown on urea compared to cultures grown on $\mathrm{NH}_{4}{ }^{+}, \mathrm{NO}_{3}{ }^{-}$or no nitrogen. In these cultures, $\mathrm{N}_{2}$ fixation represented $<1 \%$ of total daily nitrogen turnover (Mulholland et al. 1999). It appears that in some cases, urea exerts a greater control on nitrogenase activity than ammonium. In cultures of Trichodesmium sp., nitrogenase, the enzyme which reduces $\mathrm{N}_{2}$ gas to $\mathrm{NH}_{4}{ }^{+}$, was present in an inactive form when cells were grown on $\mathrm{NH}_{4}{ }^{+}$or $\mathrm{NO}_{3}{ }^{-}$as the sole sources of nitrogen, while in urea-grown cells nitrogenase was entirely absent (Ohki 1992). More recently, the first high-affinity urea transporter has been identified in the filamentous heterocystous cyanobacterium Anabaena sp. (Valladares et al. 2002). While the 
transporter appeared to be subject to nitrogen control, the urease enzyme is constitutively expressed in this strain (Valladares et al. 2002). These observations suggest that urea may be a more important source of nitrogen for cyanobacteria than previously recognized, and that urea can be involved in the ecological success of filamentous $\mathrm{N}_{2}$ fixers in the Baltic Sea region.

Further research is needed to determine whether the ecological success of nitrogen-fixing cyanobacteria is due to general nitrogen limitation of the phytoplankton community or $\mathrm{NO}_{3}{ }^{-}$depletion specifically. We have shown that a lack of $\mathrm{NO}_{3}{ }^{-}$may limit the growth of mainly diatoms while increasing the proliferation of non-diatom species, including cryptophytes, dinoflagellates and diazotrophic organisms. The latter have high uptake affinities for reduced, fixed nitrogen in addition to their ability to fix atmospheric $\mathrm{N}_{2}$.

Acknowledgements. We are very grateful to Fred Lipschultz for ${ }^{15} \mathrm{~N}$ analysis, Tina Tenson and Tönis Pöder for nutrient analysis, Urmas Lips and Laur Magi for CTD casts, and the captain and crew of the RV 'Arno'. This work was supported by grants MAST3-CT97-0149 and IC20-CT98-0109 from the European Union.

\section{LITERATURE CITED}

Andrushaitis A, Seisuma Z, Legzdina M, Lenshs E (1995) River load of eutrophying substances and heavy metals into the Gulf of Riga. In: Ojaveer E (ed) Ecosystem of the Gulf of Riga between 1920 and 1990. Estonian Academy Publishers, Tallinn, p 32-42

Antia NJ, Chorney V (1968) Nature of the nitrogen compounds supporting phototrophic growth of the marine cryptomonad Hemiselmis virescens. J Protozool 15:198-201

Antia NJ, Harrison PJ, Oliveira L (1991) The role of dissolved organic nitrogen in phytoplankton nutrition, cell biology and ecology. Phycologia 30:1-89

Balode M, Purina I (1996) Harmful phytoplankton in the Gulf of Riga (the Baltic Sea). In: Yasumoto T, Oshima Y, Fukuyo Y (eds) Harmful and toxic algal blooms. Intergovernmental Oceanographic Commission of UNESCO, Paris, p 69-72

Balode M, Purina I, Béchemin C, Maestrini SY (1998) Effects of nutrient enrichment on the growth rates and community structure of summer phytoplankton from the Gulf of Riga, Baltic Sea. J Plankton Res 20:2251-2272

Berg GM, Glibert PM, Lomas MW, Burford M (1997) Organic nitrogen uptake and growth by the chrysophyte Aureococcus anophagefferens during a brown tide event. Mar Biol 129:377-387

Berg GM, Glibert PM, Jørgensen NOG, Balode M, Purina I (2001) Variability in inorganic and organic nitrogen uptake associated with riverine nutrient input in the Gulf of Riga, Baltic Sea. Estuaries 24:204-214

Berman T (1997) Dissolved organic nitrogen utilization by an Aphanizomenon bloom in Lake Kinneret. J Plankton Res 19:577-586

Berman T, Chava S (1999) Algal growth on organic compounds as nitrogen sources. J Plankton Res 21:1423-1437

Bradley RL, Reddy KJ (1997) Cloning, sequencing and regu- lation of the global nitrogen regulator gene ntcA in the unicellular diazotroph cyanobacterium Cyanothece sp. strain BH68K. J Bacteriol 179:4407-4410

Bryant DA (1994) The molecular biology of cyanobacteria. Kluwer Academic Publishers, Boston, MA

Carlsson P, Edling H, Bechemin C (1998) Interactions between a marine dinoflagellate (Alexandrium catenella) and a bacterial community utilizing riverine humic substances. Aquat Microb Ecol 16:65-80

Carpenter EJ (1983) Nitrogen fixation by marine Oscillatoria (Trichodesmium) in the world's oceans. In: Carpenter EJ, Capone DG (eds) Nitrogen in the marine environment. Academic Press, New York, p 65-103

Collier JL, Brahamsha B, Palenik B (1999) The marine cyanobacterium Synechococcus sp. WH7805 requires urease (urea amidohydrolase, EC 3.5.1.5) to utilize urea as a nitrogen source: molecular-genetic and biochemical analysis of the enzyme. Microbiology 145:447-459

Collos Y, Siddiqi MY, Wang MY, Glass ADM, Harrison PJ (1992) Nitrate uptake kinetics by two main diatoms using the radioactive tracer ${ }^{13} \mathrm{~N}$. J Exp Mar Biol Ecol 163: 251-260

Collos Y, Vaquer A, Bibent B, Slawyk G, Garcia N, Souchu P (1997) Variability in nitrate uptake kinetics of phytoplankton communities in a Mediterranean coastal lagoon. Estuar Coast Shelf Sci 44:369-375

Droop MR (1957) Auxotrophy and organic compounds in the nutrition of marine phytoplankton. J Gen Microbiol 16: 286-293

Dugdale RC, Goering JJ (1967) Uptake of new and regenerated forms of nitrogen in primary productivity. Limnol Oceanogr 12:196-206

Edler L (1979) Recommendations on methods for marine biological studies in the Baltic Sea. Phytoplankton and chlorophyll. Baltic Mar Biol Publ 5:1-38

Fiedler G, Muro-Pastor AM, Flores E, Maldener I (2001) NtcA-dependent expression of the devBCA operon, encoding a heterocyst-specific ATP-binding cassette transporter in Anabaena spp. J Bacteriol 183:3795-3799

Frias JE, Merida A, Herrero A, Martin-Nieto J, Flores E (1993) General distribution of the nitrogen control gene ntcA in cyanobacteria. J Bacteriol 175:5710-5713

Frias JE, Flores E, Herrero A (1994) Requirement of the regulatory protein NtcA for the expression of nitrogen assimilation and heterocyst development genes in the cyanobacterium Anabaena sp. PCC 7120. Mol Microbiol 14:823-832

Glibert PM, Terlizzi D (1999) Cooccurrence of elevated urea levels and dinoflagellate blooms in temperate estuarine aquaculture ponds. Appl Environ Microbiol 65:12

Goldman JC (1993) Potential role of large oceanic diatoms in new primary production. Deep-Sea Res 40:159-168

Hallegraeff GM (1993) A review of harmful algal blooms and their apparent global increase. Phycologia 32:79-99

Hoch MP, Kirchman DL (1995) Ammonium uptake by heterotrophic bacteria in the Delaware estuary and adjacent coastal waters. Limnol Oceanogr 40:886-897

Jørgensen NOG, Tranvik LJ, Berg GM (1999) Occurrrence and bacterial cycling of dissolved nitrogen in the Gulf of Riga, the Baltic Sea. Mar Ecol Prog Ser 191:1-18

Kahru M, Horstmann U, Rud O (1994) Satellite detection of increased cyanobacteria blooms in the Baltic Sea: natural fluctuation or ecosystem change? Oceanology 23:469-472

Karl D, Letelier R, Tupas L, Dore J, Christian J, Hebel D (1997) The role of nitrogen fixation in biogeochemical cycling in the subtropical North Pacific Ocean. Nature 388:533-538 
Keil RG, Kirchman DL (1991) Contribution of dissolved free amino acids and ammonium to the nitrogen requirements of heterotrophic bacterioplankton. Mar Ecol Prog Ser 73: $1-10$

Keller AA, Rice RL (1989) Effects of nutrient enrichment on natural populations of the brown tide phytoplankton Aureococcus anophagefferens (Chrysophyceae). J Phycol 25:636-646

Koroleff F (1983) Determination of urea. In: Grasshoff K, Ehrhardt M, Kremling K (eds) Methods of seawater analysis. Verlag Chemie, Weinheim, p 158-162

Landry MR, Barber RT, Bidigare RR, Chai $\mathrm{F}$ and 9 others (1997) Iron and grazing constraints on primary production in the central equatorial Pacific: an EqPac synthesis. Limnol Oceanogr 42:405-418

LaRoche J, Nuzzi R, Waters R, Wyman K, Falkowski PG, Wallace DWR (1997) Brown tide blooms in Long Island's coastal waters linked to interannual variability in groundwater flow. Global Change Biol 3:101-114

Larsson U, Hajdu S, Walve J, Elmgren R (2001) Baltic Sea nitrogen fixation estimated from the summer increase in upper mixed layer total nitrogen. Limnol Oceanogr 46: 811-820

Laznik M, Stålnacke P, Grimvall A, Wittgren H (1999) Riverine input of nutrients to the Gulf of Riga: temporal and spatial variation. J Mar Syst 23:11-25

Lee S, Fuhrman JA (1987) Relationships between biovolume and biomass of naturally derived marine bacterioplankton. Appl Environ Microbiol 53:1298-1303

Lewitus AJ, Kana TM (1994) Responses of estuarine phytoplankton to exogenous glucose: stimulation versus inhibition of photosynthesis and respiration. Limnol Oceanogr 39:182-188

Lindell D, Post A (2001) Ecological aspects of ntcA gene expression and its use as an indicator of the nitrogen status of marine Synechococcus spp. Appl Environ Microbiol 67:3340-3349

Lomas MW, Glibert PM (1999) Temperature regulation of nitrate uptake: a novel hypothesis about nitrate uptake and reduction in cool-water diatoms. Limnol Oceanogr 44: $556-572$

Maestrini SY, Balode M, Béchemin C, Purina I, Verite C (1997) Nutrients limiting the algal growth potential (AGP) in the Gulf of Riga, eastern Baltic Sea, in spring and early summer 1996. La Mer 35:49-68

Maestrini SY, Balode M, Béchemin C, Purina I (1999) Nitrogenous organic substances as potential nitrogen sources, for summer phytoplankton in the Gulf of Riga, eastern Baltic Sea. Plankton Biol Ecol 46:8-17

Malone TC, Falkowski PG, Hopkins TS, Rowe GT, Whitledge TE (1983) Mesoscale response of diatom populations to a wind event in the plume of the Hudson River. Deep-Sea Res 30A:149-170

Meybeck M (1982) Carbon, nitrogen, and phosphorus transport by world rivers. Am J Sci 282:401-450

Mopper K, Lindroth P (1982) Diel and depth variation in dissolved free amino acids and ammonium in the Baltic Sea determined by shipbaord HPLC analyses. Limnol Oceanogr 27:336-348

Mulholland MR, Ohki K, Capone DG (1999) Nitrogen utilization and metabolism relative to patterns of $\mathrm{N}_{2}$ fixation in cultures of Trichodesmium NIBB1067. J Phycol 35: 977-988

Ohki K (1992) Regulation of nitrogenase activity in relation to the light-dark regime in the filamentous non-heterocystous cyanobacterium Trichodesmium sp. NIBB1067. J Gen Microbiol 138:2679-2685
Ohlendieck U, Stuhr A, Siegmund H (2000) Nitrogen fixation by diazotrophic cyanobacteria in the Baltic Sea and transfer of the newly fixed nitrogen to picoplankton organisms. J Mar Syst 25:213-219

Oviatt CA, Keller AA, Sampou P, Beatty LL (1986) Patterns of productivity during eutrophication: a mesocosm experiment. Mar Ecol Prog Ser 28:69-80

Paerl HW (1991) Ecophysiological and trophic implications of light-stimulated amino acid utilization in marine picoplankton. Appl Environ Microbiol 57:473-479

Palenik B, Morel FMM (1990) Comparison of cell-surface Lamino acid oxidases from several marine phytoplankton. Mar Ecol Prog Ser 59:195-201

Postgate JR (1982) The fundamentals of nitrogen fixation. Cambridge University Press, Cambridge

Sanzalferez S, Delcampo FF (1994) Relationship between nitrogen-fixation and nitrate metabolism in the Nodularia strains M1 and M2. Planta 194:339-345

Seppälä J, Balode M (1999) Spatial distribution of phytoplankton in the Gulf of Riga during spring and summer stages. J Mar Syst 23:51-67

Smayda TJ (1989) Primary production and the global epidemic of phytoplankton blooms in the sea: a linkage. In: Cosper EM, Bricelj VM, Carpenter EJ (eds) Novel phytoplankton blooms: causes and impacts of recurrent brown tides and other unusual blooms. Springer-Verlag, New York, p 449-482

Smayda TJ, Villareal TA (1989) An extraordinary, noxious browntide in Narragansett Bay. I. The organism and its dynamics. In: Okaichi T, Anderson DM, Nemoto T (eds) Red tides: biology, environmental science, and toxicology. Elsevier Science, New York, p 129-132

Sörensson F, Sahlsten E (1987) Nitrogen dynamics of a cyanobacteria bloom in the Baltic Sea: new versus regenerated production. Mar Ecol Prog Ser 37:277-284

Stal LJ, Walsby AE (1998) The daily integral of nitrogen fixation by planktonic cyanobacteria in the Baltic Sea. New Phytol 139:665-671

Stal LJ, Walsby AE (2000) Photosynthesis and nitrogen fixation in a cyanobacterial bloom in the Baltic Sea. Eur J Phycol 35:97-108

Stal LJ, Staal M, Villbrandt M (1999) Nutrient control of cyanobacterial blooms in the Baltic Sea. Aquat Microb Ecol 18:165-173

Stålnacke P, Vagstad N, Loigu E (1999) Nutrient runoff and transfer from land and rivers to the Gulf of Riga. Hydrobiologia 410:103-108

Stewart WDP, Rowell P (1975) Effects of L-methionine-DL-sulfoximine on the assimilation of newly fixed $\mathrm{NH}_{3}$, acetylene reduction and heterocyst production in Anabaena cylindrica. Biochem Biophys Res Commun 65:846-856

Stipa T, Tamminen T, Seppälä J (1999) On the creation and maintenance of stratification in the Gulf of Riga. J Mar Syst 23:27-49

Tamminen T, Seppälä J (1999) Nutrient pools, transformations, ratios and limitation in the Gulf of Riga, the Baltic Sea, during four successional stages. J Mar Syst 23:83-106

Utermöhl H (1958) Zur Vervollkommnung der quantitativen Phytoplanktonmethodik. Mitt Int Ver Limnol 9:1-38

Valderrama JC (1995) Methods of nutrient analysis. In: Hallegraeff GM, Anderson DM, Cembella AD (eds) Manual on harmful marine microalgae. IOC Manuals and Guides 33. UNESCO, Paris, p 251-282

Valladares A, Montesinos ML, Herrero A, Flores E (2002) An ABC-type, high-affinity urea permease identified in cyanobacteria. Mol Microbiol 43:703-715

Wheeler PA, Kirchman DL (1986) Utilization of inorganic and 
organic nitrogen by bacteria in marine systems. Limnol Oceanogr 31:998-1009

Yurkovskis A, Mazmachs M, Modris R (1996) Present state and historical changes of the nutrient system in the Gotland Basin and the Gulf of Riga (Baltic Sea). In: Guelorget O, Lefebvre O (eds) A comparative ecological approach of

Editorial responsibility: Karin Lochte, Kiel, Germany coastal environments and paralic ecosystems. Université Montpellier II, Montpellier, p 78-81

Yurkovskis AE, Kostrichkina E, Ikauniece A (1999) Seasonal succession and growth in the plankton community of the Gulf of Riga in relation to long-term nutrient dynamics. Hydrobiologia 393:83-87

Submitted: October 16, 2001; Accepted: September 12, 2002 Proofs received from author(s): January 10, 2003 